\title{
Aktivitas Antioksidan Ekstrak Biji Buah Areca vestiaria Giseke dan Fraksinya dengan Metode DPPH (2,2-diphenyl-1-picrylhydrazyl)
}

\author{
Nur Candra Eka Setiawan dan Hilda Amalia \\ Akademi FarmasiPutra Indonesia Malang \\ nur.candra.akfarpim@gmail.com
}

\begin{abstract}
Abstrak
Senyawa antioksidan semakin luas penggunaannya seiring dengan berkembangnya pemahaman masyarakat tentang peranannya dalam menghambat penyakit degeneratif serta penuaan dini. Biji buah pinang yaki (Areca vestiaria Giseke) mengandung banyak senyawa yang bersifat antioksidan dengan mekanisme pengkapan radikal bebas. Penelitian ini bertujuan untuk mengetahui perbedaan aktivitas antioksidan pada ekstrak dan fraksi biji buah pinang yaki dan nilai $\mathrm{IC}_{50}$ dari aktivitas antioksidannya. Dalam penelitian ini dilakukan ekstraksi dengan metode sokletasi menggunakan pelarut etanol 96\%. Kemudian dipartisi menggunakan tiga pelarut yaitu n-heksan, etil asetat, dan etanol-air. Selanjutnya dilakukan perhitungan rendemen, skrining fitokimia, dan uji aktivitas antioksidan dengan menggunakan metode DPPH. Hasil perhitungan rendemen ekstrak etanol, fraksi n-heksan, fraksi etil asetat, dan fraksi etanol-air biji buah pinang yaki berturut-turut $17,1 \%, 10,8 \%, 18,2 \%, 52,8 \%$. Skrining fitokimia flavonoid pada ekstrak etanol, etil asetat, fraksi etanol-air menunjukkan positif adanya senyawa flavonoid terhadap reagen $\mathrm{Mg}-\mathrm{HCl}$. Nilai $\mathrm{IC}_{50}$ ekstrak etanol, fraksi n-heksan, fraksi etil asetat, fraksi etanol-air berturut-turut $94,5 \mu \mathrm{g} / \mathrm{mL}, 445,7 \mu \mathrm{g} / \mathrm{mL}, 44,7$ $\mu \mathrm{g} / \mathrm{mL}, 91,4 \mu \mathrm{g} / \mathrm{mL}$. Kesimpulan dalam penelitian ini adalah ekstrak etanol biji buah pinang yaki dan fraksinya memiliki aktivitas antioksidan. Fraksi etil asetat memiliki aktivitas antioksidan tertinggi yaitu 44,7 $\mu \mathrm{g} / \mathrm{mL}$.
\end{abstract}

Kata-kata kunci: antioksidan, Areca vestiaria Giseke, DPPH

\begin{abstract}
Antioxidant widely used to prevent degeneratif desease and anti aging. The seed of Pinang yaki fruits contain some compounds which have antioxidant activity. The purposes of this research were to know the antioxidant activity of ethanolic extracts and fractions of the seed of pinang yaki fruits and the $I_{50}$ value of its antioxidant activity. The samples of the seed were prepared separately by soxhlet extraction method with ethanol $96 \%$ as the solvent. Then fractionation process used three different solvents are n-hexane, ethyl acetate, and ethanol-water. Futhermore, the calculation of yield, phytochemical screening, and test of antioxidant activity using DPPH method. Yield calculation result showed ethanolic extract, fraction of nhexane, fraction of ethyl acetate, fraction of ethanol-water 17,1\%, 10,8\%, 18,2\%, 52,8\%. Phytochemical screening of Flavonoids ethanolic extract, fraction of ethyl acetate, fraction of ethanol-water showed positive contains Flavonoid. IC 50 value of ethanolic extract, fraction of n-hexane, fraction of ethyl acetate, fraction of ethanol-water $94,5 \mu \mathrm{g} / \mathrm{mL}, 445,7 \mu \mathrm{g} / \mathrm{mL}, 44,7 \mu \mathrm{g} / \mathrm{mL}, 91,4 \mu \mathrm{g} / \mathrm{mL}$. The conclusion of this research is extract of ethanol and the fraction of seed of pinang yaki fruits has the antioxidant activity. Fraction of ethyl acetate has the higher antioxidant activity $44,7 \mu \mathrm{g} / \mathrm{mL}$.
\end{abstract}

Keywords: antioxidant, Areca vestiaria Giseke, DPPH

\section{PENDAHULUAN}

Penyakit degeneratif adalah salah satu penyakit penyebab utama kematian secara global. Dari tahun ke tahun prevalensi penderita penyakit degeneratif terus meningkat di dunia.

Penyakit degeneratif umumnya terjadi akibat kerusakan sel, jaringan lemak, protein, sistem kekebalan, dan DNA yang disebabkan oleh berbagai

factor baik terjadi secara alami, terkena radiasi, atau oleh zat - zat kimia yang bersifat karsinogenik. Ada berbagai macam teori yang dapat menjelaskan penyebab penyakit degeneratif. Salah satu teori yang dianggap cukup signifikan adalah teori reaksi radikal bebas. Kelebihan radikal bebas di dalam tubuh dapat memacu timbulnya berbagai macam penyakit degeneratif dan kronis (Pham-Huy, et al.,2008). 
Radikal bebas adalah molekul atau fragmen molekul yang mengandung satu atau lebih elektron tidak berpasangan pada orbital atomnya. Radikal bebas ini berbahaya karena sangat reaktif mencari pasangan elektronnya untuk mencapai kestabilan (Winarsih, 2007). Radikal bebas yang merusak sel tubuh ini dapat dinetralisir dengan senyawa antioksidan (Iorio, 2007).

Antioksidan adalah senyawa yang dapat menghambat oksigen reaktif dan radikal bebas dalam tubuh dengan cara memberikan satu atau lebih elektron kepada radikal bebas sehingga menjadi molekul yang normal kembali dan menghentikan kerusakan yang ditimbulkan (Sasikumar, et al., 2009). Pada keadaan normal (saat istirahat) sistem pertahanan antioksidan di dalam tubuh dapat secara mudah mengatasi radikal bebas yang terbentuk (Capelli \& Cysewski, 2006). Namun, ketika produksi radikal bebas melebihi kemampuan pertahanan antioksidan maka akan terjadi kerusakan oksidatif dan menyebabkan menurunnya imunitas terhadap penyakit dan cidera. Oleh sebab itu dibutuhkan asupan vitamin sebagai zat antioksidan tambahan.

Zat antioksidan yang berasal dari tumbuhan banyak dikembangkan dan diteliti. Sumber antioksidan dari tumbuhan banyak berasal dari senyawa fenolik, terutama flavonoid (Khumar \& Pandey, 2013). Beberapa tanaman yang memiliki aktivitas antioksidan adalah daun kenari memiliki aktivitas antioksidan sebesar 63,2\% (Lukmanto, 2015), kulit manggis memiliki aktivitas antioksidan 8,67 ppm (termasuk antioksidan kuat) (Miryanti, et al., 2011), buah bakum memiliki aktivitas antioksidan 318,6 ppm (Ridho, 2013). Bawang dayak memiliki aktivitas antioksidan 62,7 ppm (Setiawan \& Febriyanti, 2017), sedangkan sari buah tin sebesar 76.7 ppm (Wijayanti et al., 2017).

Berdasarkan penelitian yang dilakukan oleh Simbala (2006) tanaman pinang Yaki memiliki senyawa metabolit sekunder yaitu flavonoid, triterpenoid, tanin, hidrokuinon dan saponin. Penelitian yang dilakukan oleh Ismail, et al., (2012) juga menyatakan bahwa total fenolik ekstrak biji buah pinang Yaki adalah $85,9 \mathrm{mg} / \mathrm{kg}$ sedangkan antioksidan sebesar $88,2 \%$. Sehingga berdasarkan penelitian tersebut pinang yaki dapat digunakan sebagai antioksidan dan dapat digunakan sebagai alternative terapi penyakit degeneratif. Oleh karena itu diperlukan penelitian lanjutan untuk uji aktivitas pada ekstrak buah biji pinang dan fraksinya sehingga dapat diketahui fraksi mana yang memiliki aktivitas antioksidan paling tinggi.

\section{METODE}

\section{Ekstraksi dan Fraksinasi}

Sebanyak $100 \mathrm{~g}$ serbuk biji buah pinang yaki dimasukkan ke dalam selongsong soklet. Ditambahkan etanol 96\% (400 mL). Proses ekstraksi dilakukan hingga menghasilkan cairan bening. Ekstrak yang didapat dievaporasi menggunakan evaporator pada suhu $50^{\circ} \mathrm{C}$ sampai diperoleh ekstrak pekat (Mokoginta, et al., 2013).

Hasil ekstrak kemudian difraksinasi dengan corong pisah. Fraksinasi dilakukan dengan menggunakan pelarut yang berbeda yaitu etanol-air, n-heksan, dan etil asetat dengan masing-masing perbandingan 1:1. Hasil fraksi kemudian dipekatkan dan dihitung rendemennya (Sarker, et al., 2006).

\section{Skrining Fitokimia}

\section{Uji Alkaloid}

Sampel dibasakan dengan kloroform berammonia, lalu disaring. Ditambahkan $0,5-1 \mathrm{~mL}$ asam sulfat $2 \mathrm{~N}$ pada hasil filtrate, dikocok sampai terbentuk 2 lapisan. Lapisan asam (atas) dipipet dan dibagi dalam 3 tabung reaksi. Masing-masing tabung reaksi ditambahkan 2 tetes pereaksi Mayer, Wagner, dan Dragendorf. Kemudian diamati perubahan yang terjadi (Kristianti, et al., 2008).

\section{Uji Flavonoid}

Sampel diekstraksi dengan pelarut n-heksana atau petrolatum eter sebanyak $15 \mathrm{~mL}$, lalu disaring. Ekstrak yang diperoleh selanjutnya diekstraksi lebih lanjut menggunakan methanol atau etanol sebanyak $30 \mathrm{~mL}$. $2 \mathrm{~mL}$ ekstrak methanol/etanol yang diperoleh dimasukkan dalam tabung reaksi dan ditambahkan dengan 0,5 $\mathrm{HCl}$ pekat dan 3-4 pita logam $\mathrm{Mg}$. Adanya flavonoid dengan warna merah, orange dan hijau tergantung pada struktur flavonoid yang terkandung dalam sampel tersebut (Kristianti, et al., 2008)

\section{Uji Tanin}

Sampel dimasukkan ke dalam tabung reaksi dipanaskan di atas tangas air, kemudian disaring. Filtrate ditambahkan larutan besi (III) klorida $1 \%$. Adanya senyawa tanin ditandai dengan terjadinya endapan berwarna hijau (Kristianti, et al., 2008).

\section{Uji Saponin}

Sampel dimasukkan dalam tabung reaksi. Ditambahkan $10 \mathrm{~mL}$ air panas, dinginkan dan kemudian dikocok kuat-kuat selama 10 detik. Bila positif akan keluar busa/buih yang mantap selama 10 menit, setinggi $1 \mathrm{~cm}-10 \mathrm{~cm}$. Jika ditambahkan 1 asam klorida $2 \mathrm{~N}$, buih tidak hilang (MMI IV). 


\section{Uji Steroid dan Terpenoid}

Sampel diekstrak dengan pelarut $n$-heksana atau petroleum eter (kurang lebih $2 \mathrm{~mL}$ ), kemudian disaring. Ekstrak yang diperoleh diambil sedikit dan dikeringkan diatas papan spot test, kemudian disaring. Ditambahkan 3 tetes anhidrida asetat dan kemudian satu tetes asam sulfat pekat. Adanya senyawa golongan terpenoid akan ditandai dengan timbulnya warna merah sedangkan adanya senyawa golongan steoroid ditandai dengan munculnya warna biru (Kristianti, et al., 2008).

\section{Penentuan Aktivitas Antioksidan}

Penentuan aktivitas antioksidan dilakukan berdasarkan metode Molyneux (2004) dengan modifikasi. Dipipet $4 \mathrm{~mL}$ larutan DPPH $40 \mathrm{ppm}$ ditambah dengan $1 \mathrm{~mL}$ masing-masing larutan uji ekstrak dan fraksi dengan 5 varian konsentrasi. Campuran didiamkan selama 30 menit yang telah diperoleh. Larutan ini kemudian diukur absorbansinya pada panjang gelombang maksimum DPPH $516 \mathrm{~nm}$. Sebagai pembanding digunakan vitamin $\mathrm{C}$ dengan perlakukan yang sama dengan larutan uji.

Persen peredaman dihitung menggunakan rumus:

$\frac{\text { Absorbansi kontrol-Absorbansi sampel }}{\text { Absorbansi kontrol }} \times 100 \%$

Setelah didapatkan persentase inhibisi dari masing-masing konsentrasi, kemudian ditentukan persamaan $\mathrm{y}=\mathrm{bx}+\mathrm{a}$ dengan perhitungan secara regresi linear dimana $x$ adalah konsentrasi $(\mu \mathrm{g} / \mathrm{mL})$ dan y adalah persentase inhibisi (\%). Aktivitas antioksidan dinyatakan dengan Inhibition Concentration 50\% $\left(\mathrm{IC}_{50}\right)$ yaitu konsentrasi sampel yang dapat meredam radikal DPPH sebanyak $50 \%$. Nilai IC $_{50}$ didapatkan dari nilai x setelah mengganti $\mathrm{y}=50$.

\section{HASIL DAN PEMBAHASAN}

\section{Ekstraksi}

Metode ekstraksi yang digunakan adalah metode sokhletasi. Berdasarkan Mokoginta (2013) ekstraksi dengan metode sokhletasi memiliki rendemen yang tinggi akibat adanya pemanasan dan juga aktvitas penangkal radikal bebas yang tinggi dibandingkan dengan metode maserasi serta perkolasi.

Hasil ekstrak yang diperoleh yaitu ekstrak pekat berwarna kemerahan. Hasil ekstrak pekat kemudian difraksinasi dengan etanol-air,n-heksan, dan etil asetat. Hasil ekstrak dan fraksi dihitung rendemennya. Hasil perhitungan rendemen tercantum pada Tabel 1.

Fraksi etil asetat menghasilkan rendemen yang lebih besar dibandingkan fraksi lainnya karena sifatnya yang semipolar menyebabkan senyawa yang sifatnya polar lebih terkonsentrasi pada fraksi tersebut.

\section{Skrining Fitokimia}

Skrining fitokimia merupakan analisis kualitatif terhadap senyawa-senyawa metabolit sekunder. Suatu ekstrak dari bahan alam terdiri atas berbagai macam metabolit sekunder yang berperan dalam aktivitas biologinya. Senyawa-senyawa tersebut dapat diidentifikasi dengan pereaksi-pereaksi yang mampu memberikan ciri khas dari setiap golongan metabolit sekunder (Harborne, 1987).

\section{Uji Aktivitas Antioksidan}

Berdasarkan penelitian yang telah dilakukan, diperoleh data penurunan absorbansi DPPH pada larutan uji yang dapat dihitung peredaman DPPH (\%inhibisi). Semakin besar konsentrasi sampel maka semakin besar pula persen peredaman DPPH, seperti yang terlihat pada Gambar 1.

Berdasarkan dengan Molyneux (2003) aktivitas antioksidan ekstrak dan fraksi biji buah pinang yaki dinyatakan dengan $\mathrm{IC}_{50}$ sebagai parameter karena menunjukkan nilai konsentrasi yang mampu meredam 50\% radikal bebas DPPH. Menurut Ariyanto (2006) tingkat kekuatan antioksidan adalah sangat kuat $\left(\mathrm{IC}_{50}<50 \mu \mathrm{g} / \mathrm{mL}\right)$, kuat $\left(\mathrm{IC}_{50} 50-100\right.$ $\mu \mathrm{g} / \mathrm{mL})$, sedang $\left(\mathrm{IC}_{50} 101-150 \mu \mathrm{g} / \mathrm{mL}\right)$, lemah $\left(\mathrm{IC}_{50}\right.$ $>150 \mu \mathrm{g} / \mathrm{mL})$.

Berdasarkan Tabel 3 menunjukkan bahwa fraksi n-heksan memiliki aktivitas antioksidan yang sangat lemah. Aktivitas antioksidan yang sangat kuat dimiliki oleh fraksi etil asetat. Bila keempat sampel tersebut dibandingkan dengan kontrol positif vitamin $\mathrm{C}$, vitamin $\mathrm{C}$ memiliki nilai $\mathrm{IC}_{50}$ yang paling kecil diantara keempat sampel tersebut.

Fraksi etil asetat memiliki $\mathrm{IC}_{50} 44,65 \mu \mathrm{g} / \mathrm{mL}$ sehingga tergolong antioksidan kuat. Dari data skrining fitokimia fraksi etil asetat positif mengandung flavonoid, terpenoid, saponin, dan tanin. Sedangkan fraksi n-heksan positif terhadap saponin, tanin, dan steroid. Perbedaan kandungan senyawa pada kedua fraksi tersebut mempengaruh aktivitas antioksidan dan nilai $\mathrm{IC}_{50}$. Flavonoid dan terpenoid memiliki aktivitas antioksidan yang sangat kuat (Heim, 2002; Grassmann, 2005). Tidak adanya kandungan flavonoid dan tepenoid sebagai sumber 
Tabel 1. Data rendemen ekstrak dan fraksi biji buah pinang yaki

\begin{tabular}{lcc}
\hline Nama Ekstrak/ Fraksi & Bobot (g) & Rendemen (\%) \\
\hline Ekstrak etanol 96\% & 17,1 & 17,1 \\
\hline Fraksi n-heksan & 1,42 & 10,8 \\
\hline Fraksi etil asetat & 2,38 & 18,2 \\
\hline Fraksi etanol-air & 6,93 & 52,8 \\
\hline
\end{tabular}

Tabel 2. Hasil Uji Fitokimia Serbuk, Ekstrak Etanol, serta Fraksi Nheksan, Etil Asetat, dan Fraksi Air Biji Buah Pinang Yaki

\begin{tabular}{|c|c|c|c|c|c|c|c|c|}
\hline \multirow{2}{*}{ No } & \multirow{2}{*}{ Pereaksi } & \multicolumn{5}{|c|}{ Sampel } & \multirow{2}{*}{$\begin{array}{l}\text { Standar } \\
\text { (warna) }\end{array}$} & \multirow{2}{*}{ Deteksi } \\
\hline & & $\mathrm{S}$ & $\mathrm{E}$ & $\mathrm{N}$ & EA & $\mathrm{A}$ & & \\
\hline 1 & $\mathrm{HCl}+$ serbuk $\mathrm{Mg}$ & + & + & - & + & + & $\begin{array}{l}\text { Perubahan } \\
\text { warna }\end{array}$ & Flavonoid \\
\hline 2 & Dragendorff & - & - & - & - & - & $\begin{array}{l}\text { Endapan } \\
\text { merah-jingga }\end{array}$ & Alkaloid \\
\hline 3 & Mayer & - & - & - & - & - & $\begin{array}{l}\text { Endapan putih } \\
\text { kekuningan }\end{array}$ & Alkaloid \\
\hline 4 & Wagner & - & - & - & - & - & $\begin{array}{l}\text { Endapan } \\
\text { cokelat }\end{array}$ & Alkaloid \\
\hline 5 & $\begin{array}{l}\text { Air panas }+\mathrm{HCl} \\
1 \mathrm{~N}\end{array}$ & + & + & + & + & + & $\begin{array}{l}\text { Terbentuk } \\
\text { busa/buih }\end{array}$ & Saponin \\
\hline 6 & $\begin{array}{l}\mathrm{CH}_{3} \mathrm{COOH} \\
\text { anhidrat }+\mathrm{H}_{2} \mathrm{SO}_{4} \\
\text { pekat }\end{array}$ & & - & + & - & - & Warna hijau & Steroid \\
\hline 7 & $\begin{array}{l}\mathrm{CH}_{3} \mathrm{COOH} \\
\text { anhidrat }+\mathrm{H}_{2} \mathrm{SO}_{4} \\
\text { pekat }\end{array}$ & & + & - & + & + & $\begin{array}{l}\text { Warna merah - } \\
\text { cokelat }\end{array}$ & Terpenoid \\
\hline & $\mathrm{FeCl}_{3} 1 \%$ & + & + & + & + & + & $\begin{array}{l}\text { Endapan hijau } \\
\text { kehitaman-biru } \\
\text { hitam }\end{array}$ & Tanin \\
\hline
\end{tabular}

antioksidan kuat pada fraksi n-heksan sehingga mempengaruhi nilai $\mathrm{IC}_{50}$.

Aktivitas antioksidan sangat tergantung pada kehadiran gugus hidroksil dan juga jumlah serta konfigurasi gugus $\mathrm{OH}$ yang ada pada suatu molekul (Heim, 2002). Selain itu juga tergantung pada donasi atom hidrogen. Senyawa golongan terpenoid bekerja dengan cara donasi atom hidrogen sehingga menghambat terjadinya lipid peroxidation (LPO) yang berpotensi sebagai radikal bebas (Grassmann, 2005). Selain itu, adanya gugus hidroksil pada senyawa fenol dan flavonoid juga menimbulkan terjadinya aktivitas antioksidan. Hal ini dikarenakan oleh atom oksigen pada gugus hidroksil mempunyai pasangan elektron bebas yang cukup untuk

\section{DAFTAR PUSTAKA}

Andrawulan, N., Wijaya H., \& Cahyono. 1996. Aktivitas Antioksidan dari Daun Sirih (Piper betle L.). Jurnal Teknologi dan Industri Pangan, 7(1), 29-30.

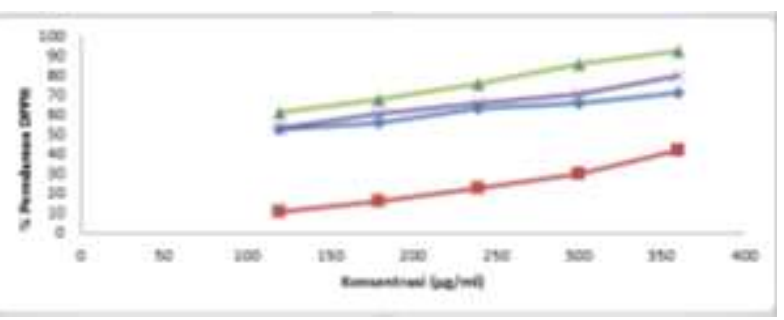

Gambar 1. Hubungan Konsentrasi dan \% Peredaman DPPH Sampel

Tabel 3. Nilai $\mathrm{IC}_{50}$ Ekstrak dan Fraksi Biji Buah Pinang Yaki

\begin{tabular}{clc}
\hline Sampel & Persamaan Regresi & IC $_{\mathbf{5 0}}(\boldsymbol{\mu g} / \mathbf{m L})$ \\
\hline \multirow{2}{*}{ Vitamin C } & $\begin{array}{l}\mathrm{y}=0,63 \mathrm{x}+27,2 \\
\mathrm{R}^{2}=0,99\end{array}$ & 36,1 \\
\hline \multirow{2}{*}{ Fraksi etil asetat } & $\begin{array}{l}\mathrm{y}=0,13 \mathrm{x}+44,3 \\
\mathrm{R}^{2}=0,99\end{array}$ & 42,6 \\
\hline \multirow{2}{*}{ Fraksi air } & $\mathrm{y}=0,11 \mathrm{x}+40,3$ & \\
& $\mathrm{R}^{2}=0,98$ & 91,8 \\
\hline Ekstrak etanol & $\mathrm{y}=0,08 \mathrm{x}+42,8$ & 93,4 \\
& $\mathrm{R}^{2}=0,98$ & \\
\hline \multirow{2}{*}{ Fraksi n-heksan } & $\mathrm{y}=0,13 \mathrm{x}-6,80$ & 447,6 \\
& $\mathrm{R}^{2}=0,98$ & \\
\hline
\end{tabular}

menghambat reaktifitas atom reaktif penyusun radikal bebas (Egwaikhide \& Gimba, 2007).

Senyawa banyak gugus hidroksil dari suatu senyawa antioksidan akan menaikkan aktivitasnya sebagai antioksidan (Andrawulan, et al., 1996). Senyawa golongan fenolik dan flavonoid memiliki lebih dari satu gugus hidroksil (polihidroksil) sehingga sangat baik dalam menetralkan suatu radikal bebas.

\section{KESIMPULAN}

Berdasarkan penelitian yang telah dilakukan dapat disimpulkan Ekstrak etanol biji buah pinang yaki beserta fraksinya memiliki aktivitas antioksidan. Fraksi etil asetat memiliki aktivitas antioksidan tertinggi dan fraksi n-heksan terendah. Ekstrak etanol, fraksi n-heksan, fraksi etil asetat, fraksi etanol-air biji buah pinang yaki memiliki aktivitas antioksidan dengan $\mathrm{IC}_{50}$ berturut-turut $94,5 \mu \mathrm{g} / \mathrm{mL}$, $445,7 \mu \mathrm{g} / \mathrm{mL}, 44,7 \mu \mathrm{g} / \mathrm{mL}, 91,4 \mu \mathrm{g} / \mathrm{mL}$.

Ariyanto, R. 2006. Uji Aktivitas antioksidan, Penentuan Kandungan Fenolik dan Flavonoid Total Fraksi Kloroform dan Fraksi Air Ekstrak Metanolik Pegagan (Centella asiatica L. Urban). Skripsi tidak diterbitkan. Yogyakarta: Fakultas Farmasi Universitas Gadjah Mada. 
Capelli, B. \& Cysewski, G. 2007. Natural Astaxanthin: King of The Carotenoids. Cyanotech: Cyanotech Corporation.

Egwaikhide, P.A. \& Gimba, C.E. 2007. Analysis of the Phytochemical Content and Antimicrobial Avtivity of Plectranthus glandulosis whole Plant. Middle-East Journal of Scientific Research, 2(3-4), 135138.

Heim, K.E., Tagliaferro, A.R., \& Bobilya, D.J. 2002. Flavonoid Antioxidants: Chemistry, Metabolism and Structure-Activity Relationship. Journal of Nutrional Biochemistry, 13, 572-584.

Grassmann, J. 2005. Terpenoid as Plant Antioxidant. Vitamin and Hormones, 72.

Harborne, J.B. 1996. Metode Fitokimia: Penentuan Cara Modern Menganalisis Tumbuhan. Terjemahan oleh Padmawinata, K., Soediro, I. Bandung: ITB Press.

Iorio, E.L. 2007. The Measurement of Oxidative Stress. International Observatory of Oxidative Stress, Free Radicals and Antioxidant Systems. Special supplement to Bulletin.

Ismail, J., Runtuwene, M.R.J., \& Fatimah, F. 2012. Penentuan Total Fenolik dan Uji Aktivitas Antioksidan pada Biji dan Kulit Buah Pinang Yaki (Areca vestiaria Giseke). Jurnal Ilmiah Sains, 12(2), 84-88.

Kristianti, A.N., Aminah, N.S., Tanjung, M., \& Kurniadi, B. 2008. Buku Ajar: Fitokimia. Surabaya: Airlangga University Press.

Lukmanto. 2015. Uji Aktivitas Antioksidan dan Penetapan Kadar Flavonoid Total Ekstrak dan Fraksi Daun Kenari (Canarium indicum L.). Skripsi tidak diterbitkan. Jember: Universitas Jember

Miryanti, Y.I.P.A, Sapei, L., Budiono, K., \& Indra, S. 2011. Ekstraksi Antioksidan dari Kulit Buah Manggis. Research Report: Engineering Science-UNPAR, 2, 1-52.

Mokoginta, E.P., Runtuwene, M.R., \& Wehantouw, F. 2013. Pengaruh Metode Ekstraksi terhadap Aktivitas Penangkal Radikal Bebas Ekstrak Metanol Kulit Biji
Pinang Yaki (Areca vestiaria Giseke). Jurnal Ilmiah Farmasi-UNSRAT, 2(04), 109-113.

Molyneux, P. 2003. The Use Of the Stable Free Radical Diphenylpicrylhydrazyl (DPPH) for Estimating Antioxidant Activity. Songklanakarin. J. Sci. Technol, 26(2), 211219.

Pham-Huy, L.A., He, H., \& Pham Huy, C. 2008. Free Radicals, Antioxidants in Disease and Health. International Journal of Biomedical Science, 4(2), 89-99.

Ridho, E.A. 2013. Uji Aktivitas Antioksida Ekstrak Metanol Buah Bakum (Cayratia trifolia) dengan Metode DPPH. Skripsi diterbitkan. Pontianak: Universitas Tanjungpura.

Sarker, D., Latif Z., Gray, I., \& Alexander. 2006. Natural Product Isolation. New Jersey: Humana Press.

Sasikumar, J.M. 2009. Antioxidant Activity and HPTLC Analysis of Pandanus odoratissimus L. Root. European Journal of Biological Sciences, 1(2), 17-22.

Sasikumar, J.M. 2009. In Vitro Antioxidant Activity of Methanolic Extracs of Berberis tinctoria Lesch. Root and Root Bark. Journal of Herbal and Toxicology, 3(2), 53-58.

Setiawan, N.C.E \& Febriyanti, A. 2017. Aktivitas Antioksidan Ekstrak Etanol dan FraksiFraksi Umbi Eleutherine palmifolia (L.) Merr dengan Metode DPPH. Journal of Current Pharmaceutical Science, 1(1), 1-5.

Simbala, H.E.I. 2006. Keanekaragaman Floristik dan Pemanfaatannya sebagai Tumbuhan Obat di Kawasan Konservasi II Taman Nasional Bogani Nani Wartabone (Kabupaten Bolaang Mongondow Sulawesi Utara). Disertasi tidak diterbitkan. Bogor: Institut Pertanian Bogor.

Wijayanti, E.D., Setiawan, N.C.E., J.P. Cristi. 2017. Effect of Lactic Acid Fermentation on Total Phenolic Content and Antioxidant Activity of Fig Fruit Juice (Ficus carica). Advances in Health Sciences Research (AHSR), volume 2: 282-289

Winarsih, H. 2007. Antioksidan Alami dan Radikal Bebas. Yogyakarta: Kanisus. 